\title{
Globalization and the Mediatization of Religion: From Scandinavia to the World
}

\begin{abstract}
Scholarship on mediatization has focused on the interactions between the institutions of the media and the realms of society that have been historically separate from those institutions, seeking to develop an empirical record that allows us to better understand the role of media in sociocultural change. The chapters in this book have sought to contribute to this field by asking: what role have the various media industries, platforms, and practices played in the unfolding of conflict, and, in turn, how have these dynamics shaped and continue to shape religion? And although mediatization research has now taken place all over the world, this book has provided a rich set of theoretically informed, empirical case studies on the role of media in exacerbating and/or assuaging conflicts around religion in contemporary Scandinavian societies, recognizing that northern Europe is the context in which much of the theoretical work on mediatization had its origins and has continued to develop. The purpose of this chapter, then, is to discuss the relevance of mediatization theory for scholars interested in the comparative analysis of the often turbulent relationship between media, religion, and conflict in national contexts outside of Scandinavia. In this chapter we examine three underlying points of connection between Scandinavian and other national contexts to explain the general salience of this book for scholars. First, we examine the significance of national myths and their relationship to an imagined homogenous community in public responses to immigration. Second, we explore processes of globalization: the worldwide realities of migration, and displacement, and the complex entanglements of religion with alterity in national contexts of secular governance. Finally, with reference specifically to current challenges to public service media, we argue that the book provides a valuable framework for further analyses of the changing ways in which media condition public engagement with religion, thus contributing to our understandings of the mediatization of religion.
\end{abstract}

Keywords: globalisation, conflict, religion, Scandinavia, national myths, mediatization of religion 


\subsection{Introduction}

Researchers from around the world have long been interested in the relationship between communication technologies and sociocultural change. In recent decades, scholars in northern Europe have been especially productive in generating research in the tradition of mediatization, exploring the ways that communication media have shaped the conditions of societal institutions throughout various epochs in history. This book has curated a series of empirical studies that have focused on conflict, considering how communication media have mediated conflict and, in turn, shaped the ways in which religion has been represented, practiced, taught, and negotiated in the public spaces of Norway, Sweden, and Denmark. Given that the cases are set in Scandinavia, the purpose of this final chapter is to explore the specificity of this context, and to flesh out how the theory of mediatization of religion as explored in this book (see Chapters 3, 4 and 17) can contribute to scholarship on the role of media, conflict, and change in other parts of the world.

It is very tempting to romanticize Scandinavian cultures and there is fairly reliable evidence to substantiate particular idealized perceptions. Norwegians are the happiest people in the world, according to the UN's 2017 World Happiness Report. When US citizens are asked to describe what they think an ideal distribution of wealth would look like in the US, the picture that emerges looks a lot like Sweden (Norton and Ariely 2011). Norway regularly tops the lists of the wealthiest and the most naturally beautiful countries on earth (Miller 2014; Tasch 2016). Scandinavian welfare states and secular democracies are the envy of the world, with relatively high income equality, healthy labor unions that defend workers' rights, pluralist, coalition-based political systems, and relatively low unemployment rates (Mulvad and Stahl 2015). Scandinavians are perceived as healthy, happy, beautiful people who live in beautiful places: they seem 'practically perfect in every way', enthuses British journalist Michael Booth (Worrall 2015).

Scandinavians, as the studies here reveal, see themselves as individualistic and rational, secular and tolerant, and as supporters of democratic governments that earn trust by protecting the rights of all (see Chapters 1 and 2). For example, since 1766, Swedish law has granted public access to government documents unless they fall under special secrecy restrictions. It is the oldest piece of freedom of information legislation in the world (Eck and Fariss 2017). Robust public service media systems that promote pluralism and tolerance are understood as the bedrock of participatory social democracy, and Scandinavian public media generally appear to avoid the worst excesses of racism (see Chapter 5). Or so it 
looked until the autumn 2015 when seemingly uncharacteristic racialized resentment in Scandinavia was expressed in public and media forums at the number of new arrivals, mainly Syrian and Iraqi refugees and asylum seekers (Tanner 2016). Such sentiments are by no means unprecedented but they acquired an alarming intensity as racist and xenophobic sentiments were being more openly expressed and right-wing populist movements seemed to be gaining a greater foothold across Scandinavia. ${ }^{1}$ The risible case of an anti-immigrant Norwegian group mistaking empty bus seats for Muslim women wearing burqas captured the absurd extremes of Islamophobic rhetoric. ${ }^{2}$ Europe's migration crisis had reignited debates about immigration linked to controversies about religion that had been sparked a decade earlier by the publication of the Muhammad cartoons in the Danish Jyllands-Posten. Such discouraging and troubling responses challenged visions of Norway, Sweden, and Denmark as tolerant and welcoming societies, calling into question the very strength of the democratic institutions and egalitarian values upon which they pride themselves.

Media controversies that implicate religion as $a$ or the source of conflict provide templates for understanding the mediatization of religion (see Chapters 3 and 4). As this book has noted, Hjarvard, Mortensen, and Eskjaer (2015) have described the role of conflict in mediatization processes (see Chapter 3) in relation to three dynamics. First, the media amplify an event or phenomenon by reporting on it in particular ways using specific templates. Second, the institutional logics and practices of media professionals play a role in framing the phenomenon. And third, the media co-structure power relations by providing the platforms for the staging and performance of conflicts.

The dominant media framing of the Muhammad cartoon controversy, for example, was that of a 'culture war' - a battle between Denmark's Christian heritage and a confrontation with Islam. The news media amplified Samuel Huntingdon's 'clash of civilizations' trope that was promulgated after the attacks of 11 September 2001 (Eine, Risto, and Phillips 2008). Public and media responses

1 David Zucchino, “'I’ve Become a Racist': Migrant Wave Unleashes Danish Tensions Over Identity,” The New York Times, 5 Sept 2016, accessed 25 Sept 2017, https://www.nytimes.com/2016/09/ 06/world/europe/denmark-migrants-refugees-racism.html;

Alberto Nardelli and George Arnett, "Why Are Anti-Immigration Parties So Strong in the Nordic States?” The Guardian, 19 June 2015, accessed 1 Sept 2017, https://www.theguardian. com/news/datablog/2015/jun/19/rightwing-anti-immigration-parties-nordic-countries-denmarksweden-finland-norway

2 Jon Henley, "Bus Seats Mistaken for Burqas by Members of Anti-Immigrant Group," The Guardian, 2 Aug 2017, accessed 1 Sept 2017, https://www.theguardian.com/world/2017/aug/02/ bus-seats-mistaken-burqas-anti-immigrant-group-norwegian 
to the 'refugee crisis' in Scandinavia, as elsewhere, similarly reproduced this kind of binaristic thinking, linking refugees with Islam and with terrorism, and creating an opposition between deserving and fake refugees (Chouliaraki, Georgiou, and Zaborowski 2017). Some media reports then suggested that terrorists and rapists were hiding amidst the new arrivals, provoking spirals of public fear and social insecurity (Gillespie et al. 2016). Social media platforms then served as primary locations where conflicts over these understandings played out, with various groups and individuals striving to reinforce or reframe dominant assumptions.

Processes of mediatization, like those of urbanization and globalization, have their roots in the rise of institutionalization, as autonomous industries, structures, and organizations began to coalesce in the realms of religion, education, science, politics, and trade. It was during the late modern period that media began to emerge as a series of semi-autonomous industries and related practices that were then integrated into "the very fabric of human interaction (Hjarvard 2012, 30). Studies of mediatization have explored how particular domains of society that have become institutionalized - politics, religion, education, trade, for example - and the various sociocultural aspects of that domain - including a domain's organizations, norms, and practices - have been potentially affected by the media. Mediatization studies, then, are especially interested in teasing out how the institutional, technological, or cultural aspects of how one or more of these domains have changed within a broad timescale.

In this book, religion has been viewed as 'a practice of mediation and a form of social interaction within which meaning-making takes place' (Lövheim 2011). Religion is an institution in that religion refers to both individual and collective practices and the organizational settings through which some of those practices are codified and passed down through generations. The claim of the book overall, then, is that religion as a societal domain, including especially its form in public spaces, is transformed over time in tandem with the societal domain of the media. And a focus on the mediatization of religion brings attention to how overall changes, of which media are a part, contribute to new forms of action and interaction and give shape to how we think of humanity and our place in the world. Thus the authors of this book argue that processes of mediatization give rise to how humans understand their relationships with one another and with those very domains (Clark 2011).

Processes of othering, of structuring social identities and differences are inherent in the mediatization of religion. Ritualistic representations of Islam as a primary cause of cultural conflict are now so deeply embedded in European and North American public and media imaginaries that they are very difficult to dislodge. Such media templates have done little to advance public understanding of 
either religion or conflict, but they are vital to the cyclical reproduction of insecurity (Gillespie and O'Loughlin 2017).

The studies in this book show that many so-called 'religious conflicts' have less to do with religion or culture than with endemic processes of globalization: new nationalisms, failed states, militarism, migration flows, economic interdependence, ecological degradation. Poverty, inequality, and oppression are the principal driving forces of societal conflicts that implicate religion or mobilize it for political purposes. As a consequence, it is important to reframe investigations of 'religious conflicts' in the wider context of globalization processes. In our own work as ethnographers, we have advocated a mixed method approach to the study of these sociocultural conflicts, foregrounding the empirical analysis of historical documents and lived experiences within specific domains so as to shed light on the contours of these changes while also resisting a presentism that might overemphasize newness at the expense of continuity. We believe that this is an important first step towards offering more nuanced analyses of the various ways in which religion is imagined, constructed, and implicated in conflict.

In examining mediatized controversies that implicate and mobilize religion, the studies in this book enable us identify the various textual politics at work in depictions of conflict, including forms of orientalising and demonizing, denigration and idealization, and sublimation and displacement. Rather than presuming the meanings ascribed to religion, it becomes possible to see when, how, and where religion emerges as a controversial issue, as a cause of conflict, or indeed as a means of conflict resolution. In this way, the book offers a prism through which further analyses and comparative case studies can develop. But the key question for scholars unfamiliar with Scandinavian national contexts remains: How might we tease out from these Scandinavian studies the wider implications for the ways in which we research the role of media in producing and reproducing 'religious controversies', as well as conditioning public engagement with religious conflict in other parts of the world? To answer this question we argue that not only do we need a global and a comparative perspective, but also an historical approach to situate practices of othering in myths of national origin and to explicate how media are linked to processes of socio-cultural change over the longue durée.

\subsection{Ancient and Modern Myths of Nationhood}

This book explores the particularities of Scandinavian countries but what is perhaps most interesting and surprising for the non-Scandinavian reader is not how 
different Scandinavians are when it comes to questions of the relations between religion, nation, and ethnicity, but how similar they are to many other places in the world in the ways that broad historical processes shape contemporary conflicts. Like most European countries, they experienced nationalist fervor and anti-Semitism before World War II. They also have complex intertwined histories of colonialism, with Greenland first being ruled by Norway and then Denmark, and then later the Swedish Gold Coast being taken over by Denmark (and the Dutch). And they, too, have seen a growth in right-wing populist nationalism, not unlike recent similar developments in France, Germany, and Switzerland, as well as in the US and UK.

Scandinavian countries, moreover, share with other liberal secular democracies around the world a certain idealism about how citizens can and should work together for the public good via democratic decision-making, and in so doing sustain a common national identity. This idealism can be characterized as based on a unifying societal myth, following the work of Roger Silverstone who, in turn, drew upon anthropological concepts and theories of religion, in particular those of Clifford Geertz and Mircea Eliade. Silverstone argues that myths are not logical or rational but they hold often-inexplicable, emotionally satisfying deep meanings for collectivities (Silverstone 2006). This is not just true of ancient myths but also holds for television and film. Despite their reliance upon recognizable genres and narratives, media myths are not static. Ancient myths and contemporary media narratives have two important and complementary dimensions, Silverstone argues: they are collective and constraining. They are collective in the sense that the narratives must elicit some degree of consensus and acceptance, and hence reinforce the values and viewpoints that are most central - to at least a large segment of a community at any one moment. Myths are also constraining because, in the requirement to resonate with expectations, mythical codes tend to reinforce hierarchies of actually existing social relationships. Cultural contexts of production constrain expectations and shape the reception of myths.

To us as scholars based in the US and UK, Scandinavian myths of the origins of democratic governance appear to have strong echoes with American and British national narratives. They involve stories about, for example, the rise of democracy out of various workers' movements that resulted in conflict that ultimately challenged monarchical sovereignty and brought about more representative forms of governance. There are also stories about how contemporary structures of governance arise out of a primordial national identity rooted in the mists of time bearing essential defining traits and values. Such myths of national identity encapsulate a common historical trajectory and destiny: in particular the shift from monarchy to self-governance and from ethno-cultural homo- 
geneity to diversity. Myths of the origins of democratic governance rooted in cultural homogeneity are deeply entwined in the flourishing of contemporary antiimmigrant populist movements and their visions of society - an important part of 'the context' to be factored in when explaining how public responses to migrant religion and socio-political conflict evolve.

National myths of cultural and religious homogeneity are especially perverse in the US context. In excluding North American Indians, the national story wraps the earliest waves of settler migration into a myth of manifest destiny, denying the realities of extermination, ethnocide, and exploitation. The point here is that while the style in which the 'imagined community' of the nation is conceived is unique (Anderson 1983), national myths and rituals that are represented and performed via media function in similar ways across societies - to include and exclude, to draw boundaries between those who belong and outsiders. By investigating how mediatized national myths operate in Scandinavian countries, this book brings to light how their collective and constraining features can be compared with other contexts. This can help other scholars arrive at a better understanding of how mediatized unifying myths of origin, by their very nature, position migrants' cultures and religions as disruptive and other, and how they work to reproduce a particularistic national sense of belonging and identity. But we can only get so far with this historical perspective. We must also situate current debates about cultural conflicts, migrant religions, and public controversies in the wider contexts of the forces driving globalization and forcing migration.

\subsection{Shared Worldwide Realities of Migration and Forced Displacement}

This book was researched and written in the context of the greatest period of forced displacement in recorded history. The UN Refugee Agency's (UNHCR) Global Trends Report found that in 2015, 65.3 million people, or one person in every 113 globally, were displaced from their homes due to war and persecution. Children made up 51 percent of the world's refugees. The number of recent, internally displaced people and refugees fleeing their countries was four times higher than it was in 2014. These migrations are directly related to longstanding and ongoing political conflicts in Iraq; others, such as those in Somalia and Afghanistan, have lasted more than three and four decades respectively, while the war in Syria is in its seventh year as we write. Seemingly intractable conflicts have been occurring more frequently, 
yet the rate of effective solutions and resolutions of conflicts is slowing down (Edwards 2016) or is even a total failure as with Syria.

Around the world, successive conflicts and the resulting tumult have shaped patterns of migration, displacement and diaspora formations, as have natural and environmental disasters, and dreams of better economic opportunity. Today, London is home to the most ethnically diverse population in the world, largely as a result of migration from former UK colonies in the post-World War II period. The US and Russia have the second and third largest numbers of foreign-born residents, with the journey from Mexico to the US being the most frequent migrant journey in the world. The countries with the highest shares of foreign-born workers are the United Arab Emirates, Qatar, Kuwait, and Bahrain - all of which are rich in resources especially compared with their neighboring countries (Inkpen 2014).

Nation-states throughout the world have long experienced migration and demographic shifts as a result of invasions, slavery, human trafficking, disasters, and labor opportunities. The $16^{\text {th }}$ century saw notable changes in the US, the UK, and central European countries' populations due to heightened trade and a desire to escape persecution. Changes to the populations in Brazil, Russia, India, and China began occurring later, dating back to the $19^{\text {th }}$ century in response to the labor demands that arose with the abolition of slavery. The late $19^{\text {th }}$ and $20^{\text {th }}$ centuries saw the development of immigration laws and border policies and practices that triggered a net emigration of educated workers from China, India, the Middle East, and many Asian countries to former colonizing countries. Some countries, like Portugal, have changed more recently from countries of net emigration to net immigration due to a strengthening economy and the end of right-wing authoritarian regimes.

Throughout these shifts, like many countries in central and southern Europe, Sweden, Norway, and Denmark maintained largely stable populations, although these countries experienced significant outward migration from the mid-19 ${ }^{\text {th }}$ until the early part of the $20^{\text {th }}$ century due to economic pressures. These trends began to change following the Second World War. Now with the strengthened economies of Scandinavian societies, they have become very attractive sites for migrants, and for Iraqi, Afghan and Syrian refugees in particular (Tanner 2016).

The war in Syria has been devastating. In 2016, from an estimated pre-war population of 22 million, the UNHCR Global Trends report identified 13.5 million Syrians requiring humanitarian assistance, of which more than 6 million are internally displaced within Syria, and around 5 million are refugees outside of Syria. In 2018 as this book goes to press the figures reported by the UNHCR are even higher: 6.5 million displaced within Syria, 5.6 million refugees have fled and 3 million are in neighbouring countries. An inestimable 884.000 asylum 
claims in total. ${ }^{3}$ The countries that have taken the highest number of Syrians are Turkey, Jordan, and Lebanon. Conflicts in Yemen, Somalia, South Sudan, and the Central African Republic are resulting in refugees in Chad, Nauru, Mauritania, Kenya, and Djibouti. The fact is that we are living through a time of displacement of unprecedented scale and scope, and its consequence is the shared global reality of complex migratory flows, and will be for a long time to come.

One key difference between the countries in Scandinavia and other countries is that, as noted in this book's first chapter, Scandinavian countries are relatively small in population size. As a result, demographic shifts following recent immigration have been felt more intensely. Size matters. This is reflected in a common media framing of immigration controversies - the numbers game. A great deal of media debate revolves around two dominant public perceptions: first, that there are just too many of 'them' coming and second, that 'the welfare state' simply does not have the resources to cater for 'them' and for 'us', and 'we' will be the losers. These fearful representations and perceptions combine with an already potent, intense social anxiety around accelerated social change caused by complex external and internal factors. This (re)produces a toxic mix of public unease that becomes fixated on immigration as the main cause of all social ills. Social insecurity becomes indissolubly tied to fears about immigration, calling into question Scandinavian self-identification as welcoming and tolerant. Competition over scarce resources can very quickly topple myths of tolerance. These mediatized chain reactions have historical and comparative precursors and precedents and are common in many countries. Understanding these common threads between nations as well as their differences is very important.

It should be noted that Sweden has taken in more asylum seekers and refugees in the last two years than any other European nation (relative to its size), including Germany, and Sweden's provision for refugees is widely regarded among European refugee support groups as exemplary. But for others, Sweden, though a 'humanitarian superpower', has become a textbook case of how not to tackle immigration - taking too many asylum seekers in and not managing their integration well. ${ }^{4}$ One of the very compelling and most valuable aspects of this book is the ways in which it highlights differences among Scandinavian countries, offering rich opportunities for comparisons at the cross-national level not just from case studies but from survey data. Another valuable aspect is

3 UNHCR, “Syria Emergency,” accessed 1 Sept 2017, http://www.unhcr.org/uk/syria-emergency. $\mathrm{html}$

4 Tove Lifvendahl, "How Sweden Became an Example of How Not to Handle Immigration," The Spectator, 3 Sept 2016, accessed 25 Sept 2017, https://www.spectator.co.uk/2016/09/how-swedenbecame-an-example-of-how-not-to-handle-immigration/ 
the recognition that there are contexts that still hold greater trust in societal institutions than is the case in the US, UK, and elsewhere in the world (Gray 2016). Will current conflicts and controversies, as they are amplified, framed, and played out in commercial social media spaces, contribute to a rejuvenated sense of trust in societal institutions, or in an undermining of that trust? Only time will tell. Finally, this book is telling in that it reveals a tendency to view recent religious controversies through the lens of 'culture wars' that position religion in opposition to the secular and as a source of conflict rather than of collaboration.

\subsection{Contesting the lens of 'Culture Wars'}

Although about half of the Scandinavians in the 2015 CoMRel survey regard Islam as a threat to their national culture, a majority do not support hostility towards foreigners (Chapter 2). This suggests a greater fear of religious than of national differences. The book shows that the struggle between secularized versions of religion and traditional, conservative and fundamentalist versions of religion is understood in quite specific terms - primarily as a struggle between Christian heritage and militarized Islam. Such a predominant 'culture war' lens of a Christian 'us' and a militant Muslim 'them' is deeply contested and disputed, but remains compelling for some and difficult to dislodge (Hunter 1992; Fiorina 2010). Dogmatic beliefs about the incompatibility of Islam with Christian Scandinavian society are often closely tied to myths of origin and of the nation, as described above, that portray a transition from harmonious homogeneity to intrusive diversity.

There is little doubt about the realities of Islamist terrorism - or indeed about other religious fundamentalisms that are rooted similarly in complex historical political and economic relationships. But in recent years Islamist-inspired attacks by different groups have received much greater media prominence and the mediatization of these events conforms to certain patterns that condition and shape public responses and can reinforce the 'us' vs. 'them' frame. Reports on attacks include those on Paris (2015 and 2017), on Beirut (2015 and 2017), and on the Kandahar airport in Afghanistan (2015), the attacks against the Sehwan worshippers in Pakistan (2017), the Palm Sunday attacks on Christian churches in Tanta and Alexandria, Egypt (2017), and Boko Haram attacks in northern Nigeria (2015). The US and UK have also experienced attacks, in London (2005, 53 killed and more than 700 injured) and Westminster (2017), as well as an earlier attack on the Israeli embassy in London in 1994. The US attack in San Bernardino (2015) followed the attacks on New York City and Washington, DC, in 2001 in 
which nearly 3,000 were killed and 6,000 injured. This was when the frame of 'culture war' first came into focus for US citizens, centered on the question of the relationship between Islam and terrorist violence. In 2017, the seven-country immigration ban Trump imposed brought conflicting approaches to migration to the forefront of media and public debate once again.

What is often overlooked is the way that ritualistic media responses to these attacks provoke and exacerbate social insecurity, and bring about grave consequences for those seeking asylum and reunification with families already in the UK or US who have no connection with terrorism or terrorist acts. And violent conflict, of course, is not confined to those affiliated with Islamist organizations. Some strains of Buddhism have become militant, for example in Myanmar where the current torture and expulsion of Rohingya Muslims continues to shock the world. The 2011 killing of 77 people in Norway was carried out by a right-wing extremist claiming affiliation with Christianity, and the US has seen a rise in similar terrorist acts carried out by extremists with Christian affiliations (ADL 2017).

Islam, like all religions, is both a set of principles and practices with cultural precepts, but legacy news media sources have tended to portray Islam as homogeneous, one dimensional and inherently violent. But this is misguided, as religious wars of the medieval period that sought to reclaim Muslim-dominated lands for the Latin church serve as a reminder that religions are never inherently violent or non-violent; such characterizations are too simplistic and unhelpful. By calling the 'culture wars' framework into question, this book moves the discussion forward - reframing current conflicts as in large part due to struggles over material resources that have resulted from centuries of exploitation in certain parts of the world for the benefit of those living other parts of the world.

Scandinavian nations see themselves as largely secular despite the lengthy tradition of Lutheran state religion. This may be due to the fact that over time, paradoxically, religion itself has undergone a process of secularization. The notion of the secular in any case is itself very slippery (see Chapter 4). Nevertheless the very concept of secular democracy sets the tone and the conditions in which the publicness - the visibility and audibility - of religion can be expressed. In Scandinavia, even Christianity, if practiced 'too fervently', can be perceived as just as much a threat to national identity as the zealous practice of Judaism or Islam (see Chapters 6-8).

The notion of secular Scandinavia may well be misleading and need to be challenged. The book shows how some citizens contest claims about a transition in Scandinavian society from Christian Lutheran values and traditions towards secularism. Such a recognition draws attention to the fact that the notion of the secular only derives its meanings by its association with the Christian religion and the sacred. The media play with the scared-secular distinction in 
ways that defy easy categorization (Knott, Poole, and Taira 2013). This is something we need to grapple with in understanding the mediatization of religion around the world and its role in effecting socio-cultural change. While the book privileges the concept of mediatization and its potential role in precipitating socio-cultural change, we must keep in perspective that media - especially public service media - are undergoing profound challenges and transformations, as well.

\subsection{Media as Sites of Contestation in Democratic Governance}

In the Scandinavian context, the concept of public service media refers mainly to legacy news media, as these organizations are charged with reflecting and shaping public opinion (see Chapter 5). By public service media, we mean mainly broadcasting and online media funded by the state rather than the press and other publications which are mainly funded privately. Public service media are seen to play an important role in both sparking and managing public debate about religion (through framing, as mentioned in Chapter 9). Because public service media are expected to reflect widely held views of tolerance, they also are understood to shape the ways that controversies around religion are represented and negotiated in reception processes and social interaction. In this book public service media are seen as playing a catalytic role in exacerbating as well as assuaging conflict. They are deemed to have a social responsibility to contain and productively manage conflict (see Chapter 5). Religious publications are viewed as somewhat apart from this mandate, and reflect alternative perspectives (see Chapter 10). However, the media thrive on controversy and conflict in order to attract and maintain audiences and, in their predisposition to dramatize and even sensationalize events, they reinforce the semantic and symbolic connections between religion and controversy. So we argue that there is a structural conflict in public service media - on the one hand to promote tolerance and multiculturalism, and on the other to secure audiences' attention via conflict and controversy. The same may be said for how teachers try to arrest the attention of their pupils by focusing on conflict and controversy (see Chapter 14).

But the news media, too, have themselves become a hotly contested topic as allegations of 'fake news' and post-truth media abound. Scandinavian countries are no exception in having witnessed a massive decline in audience share for public service media as Facebook, Google, Amazon, Netflix, and other services divert audiences' attention. Media, like migration, are increasingly best under- 
stood as part of processes of globalisation. What happens elsewhere in the world is immediately transmitted and circulated, with social media users often breaking news well before broadcast and print media. Moreover, when people migrate, they carry media preferences with them. The emergence of diaspora communications and media, the challenges of social media, and the potency of global media corporations and instantaneous and perpetual digital connectivity profoundly alter the centrality of public service media in any one nation-state and public service media's ability to condition public responses to controversies.

In February 2017, for instance, when Donald Trump defended his ban on travel from seven Muslim-majority countries by claiming that Sweden had suffered Islamist terrorist attacks the night before, this baffled Swedish audiences who had experienced no such thing. The statement was one of hundreds of falsehoods uttered by the US president, many of which had their origins in the commercial and highly partisan US news organization Fox News (Tronarp and Sundholm 2017; Eck and Fariss 2017). But the falsehood was also clearly intended to construct a boundary between 'us' (those of us who are victims or prospective victims of terrorist attacks) and 'them' (those who are imagined as perpetrators or supporters of such acts). It touched upon the myth of the nation and the 'other' as it circulated through memes, tweets, image macros, and other forms of social media. In much of the theorizing about media, news media have been understood as institutions that orchestrate relations between various societal actors and institutions in a democracy through established professional ethics, but when that role is jeopardized, it makes citizens wonder who they can trust. Politicians and media are among the least trusted professionals (Skinner \& Clemence 2017).

The book offers important insights into the multifarious intersections of social media and public service media, including why users may or may not want to share and/or discuss matters of religion in online spaces (Chapter 12), and how they discuss matters of religion in public debate (Chapter 10) and in schools and their online portals (Chapters 13-15). Social norms about which kinds of speech acts are permissible in public spaces emerge as factors of great interest. Who is allowed to speak about what is a persistent topic of debate too among public media producers charged with attracting huge audiences while also fostering greater awareness and tolerance (see Chapter 5). The case studies in this book open the door to considering the many ways in which the theories of mediatization have been rooted in a 'legacy media' and a public service media model that has been surpassed by social media. Indeed mediatization theorists these days, e.g. Stig Hjarvard, are very much concerned with analysing social media.

While this book was being finalized, a song denouncing UK Prime Minister Theresa May as a 'liar' climbed the charts of Amazon UK's downloads despite 
receiving no mainstream radio airplay due to impartiality guidelines (Weaver 2017). Such examples cause us to wonder whether our very concepts rooted in legacy media need fundamental revision in light of social media. Mediatization theorists have been grappling with how best to understand and research social media and the ways in which these platforms have created new centers of power that have unforeseen and unforeseeable implications for the exacerbation of social and political conflicts. Social media both empower civil society and enrich corporate actors like Facebook who are increasingly garnering the kind of editorial authority once ascribed to institutional media. This book offers important insights into how these dynamics play out in contemporary controversies about religion and conflict. The implication of the book is that we need to protect public service media more than ever in the face of the onslaught of social media and their partisan echo chambers, and the steady erosion of public media systems that can provoke national conversations and therefore approximate the ideals of a public sphere of democratic communication.

\subsection{Conclusion}

This chapter has focused on why scholars outside the Scandinavian context might find in this volume many points of connection worthy of further dialogue and exploration. First, we noted that all modern nations produce foundational myths of origin and destiny even if the style in which they are imagined is very different. Myths of the birth of democratic governance in Norway, Sweden, and Denmark has striking parallels with those of the US and UK. While the book underscores differences between Scandinavian countries, such parallels provide rich comparative material on which to build.

Second, we argued that like in Scandinavia, many countries around the world are experiencing the effects of globalization, migration, and displacement. Such experiences represent a shift from out- to in-migration in Scandinavian countries, offering a distinctive vantage point from which to compare countries. All over the world states are grappling with migration, changing populations and cultural and religious change. It is vital to understand how our interwoven histories also present us with moral responsibilities in situations of humanitarian need. Sweden presents a good case in point to compare with other European nations in terms of how they have responded to the current 'migration crisis' and to ensuing socio-cultural change.

Third, we argued that many nations around the world are struggling to deal with the tensions that arise between a commitment to secular governance and the realities of living in a world in which religion remains a vital social force. 
Its resurgence and renewed public visibility underscore the fact that modern nations are shaped by their own particular religious histories and that viewing conflicts through the lens of culture wars is divisive.

To the extent that this book considers the evolving role of media in democratic governance, and the specific contours of religion and religious conflicts within that governance, it provides a means of exploring the particular conditions under which mediatized conflicts might produce worse or better outcomes for peaceful multicultural co-existence. In exploring the role of media in how conflicts are constructed, constituted, and reproduced in Scandinavia, the book also provides a framework for scholars elsewhere who similarly want to understand, and respond to, the cyclical and ritual, systemic and changing role of the media in relation to the state and other political and social institutions. In so doing it affords a deeper understanding of the specific nature of and particular conditions under which mediatized conflicts that implicate religion might get worse or get better over time.

\section{Bibliography}

ADL (Anti-Defamation League). 2017. A Dark and Constant Rage: 25 Years of Right Wing Terrorism in the United States. New York: ADL. https://www.adl.org/sites/default/files/ documents/CR_5154_25YRS\%20RightWing\%20Terrorism_V5.pdf

Anderson, Benedict. 1983. Imagined Communities: Reflections on the Origin and Spread of Nationalism. London: Verso.

Chouliaraki, Lilie, Myria Georgiou, and Rafal Zaborowski. 2017. "The European 'Migration Crisis' and The Media: A Cross-European Press Content Analysis.” Project report, Department of Media and Communications, London School of Economics and Political Science. Accessed 25 Sept 2017. http://www.lse.ac.uk/media@lse/research/Media-andMigration/Migration-and-media-report-FINAL-June17.pdf

Eck, Kristine, and Christopher J. Fariss. 2017. “No, Sweden Isn’t Hiding an Immigrant Crime Problem. This Is The Real Story.” Washington Post, 24 Feb. Accessed 3 June 2017. https://www.washingtonpost.com/news/monkey-cage/wp/2017/02/24/no-sweden-isnthiding-an-immigrant-crime-problem-this-is-the-real-story/?utm_term $=.2943 \mathrm{fc} 294 \mathrm{e} 63$

Edwards, Adrian. 2016. Global Forced Displacement Hits Record High. UN Refugee Agency, 20 June. Accessed 22 April 2017. http://www.unhcr.org/news/latest/2016/6/5763b65a4/ global-forced-displacement-hits-record-high.html.

Eide, Elisabeth, Risto Kunelius, and Angela Phillips, eds. 2008. Transnational Media Events: The Mohammed Cartoons and the Imagined Clash of Civilizations. Gothenburg: Nordicom Fiorina, Morris. 2010. Culture War? The Myth of a Polarized America, $3^{\text {rd }}$ ed. Boston: Longman. Gillespie, Marie, and Ben O’Loughlin. 2017. “The Media-Security Nexus: Researching Ritualised Cycles of Insecurity." In Routledge Handbook of Media, Conflict and Security, edited by Piers Robinson, Philip Seib, and Romy Frohlich, 51-67. New York: Routledge. 
Gillespie, M., Ampofo, L., Cheesman, M., Faith, B., Iliadou, E., Issa, A., Osseiran, S., Skleparis, D., Mapping Refugee Media Journeys: Smartphones and Social Media Networks. Milton Keynes: Open University. http://www.open.ac.uk/ccig/sites/www.open. ac.uk.ccig/files/Mapping\%20Refugee\%20Media\%20Journeys\%2016\%20May\%20FIN\% 20MG_0.pdf

Gray, Alex. 2016, December 21. “Do you trust other people? Don’t worry, most people don't trust you either.” World Economic Forum. Available: https://www.weforum.org/agenda/ 2016/12/if-you-live-in-a-nordic-country-then-you-probably-trust-others-a-mediterraneancountry-forget-it/

Hunter, James Davison. 1992. Culture Wars: The Struggle to Control the Family, Art, Education, Law, and Politics in America. New York: Basic Books.

Inkpen, Christopher. 2014. "Seven Facts About World Migration." FactTank: News in the Numbers, 2 Sept. Pew Research Center. Accessed 3 June 2017. http://www.pewresearch. org/fact-tank/2014/09/02/7-facts-about-world-migration/.

Knott, Kim, Elizabeth Poole, and Teemu Taira. 2013. Media Portrayals of Religion and the Secular Sacred: Representation and Change. London: Routledge.

Marglin, Jessica. 2015. "ISIS vs. Islam." Huffington Post, 23 Nov. http://www.huffingtonpost. com/jessica-marglin/isis-vs-islam_b_8613826.html

Miller, Lisa. 2014. "25 Reasons Why Norway is the Greatest Place on Earth." Huffington Post, 7 Jan. http://www.huffingtonpost.com/2014/12/31/norway-greatest-place-on-earth_n_ 4550413.html

Mulvad, Andreas Møller, and Rune Møller Stahl. 2015. “What Makes Scandinavia Different?” Jacobin, 4 Aug. https://www.jacobinmag.com/2015/08/national-review-williamson-ber nie-sanders-sweden/

Norton, Michael I., and Dan Ariely. 2011. "Building a Better America - One Wealth Quintile at a Time." Perspectives on Psychological Science 6 (1): 9-12.

Olesen, Thomas. 2016. "Malala and the Politics of Global Iconicity." The British Journal of Sociology 67 (2): 307-327.

Silverstone, Roger. 2006. Media and Morality: On the Rise of the Mediapolis. Cambridge: Polity Press.

Skinner, Gideon and Michael Clemence. 2017, November 29. "Politicians remain the least trusted profession in Britain.” IPSOS MORI Game Changers. Available: https://www. ipsos.com/ipsos-mori/en-uk/politicians-remain-least-trusted-profession-britain

Tanner, Arno. 2016. "Overwhelmed by Refugee Flows, Scandinavia Tempers its Warm Welcome." Migration Policy Institute, $10 \mathrm{Feb}$. http://www.migrationpolicy.org/article/over whelmed-refugee-flows-scandinavia-tempers-its-warm-welcome

Tasch, Barbara. 2016. "The 25 Richest Countries, Ranked.” Business Insider, 31 March. Accessed 3 July 2017. http://www.businessinsider.com/the-richest-countries-in-the-world-2016-3.

Tronarp, Gustaf, and Magnus Sundholm. 2017. “After Trump’s 'Last Night in Sweden’: Here are the Errors in Fox News' Report on Swedish Immigration." Aftonbladet, 19 Feb. Accessed 1 June 2017. http://www.aftonbladet.se/nyheter/a/g26Lk/after-trumps-lastnight-in-sweden-here-are-the-errors-in-fox-news.

Weaver, Matthew. 2017. “'She's a liar, liar’: Anti-Theresa May Song Heads to Top of Charts.” The Guardian, 31 May. Accessed 1 June 2017. https://www.theguardian.com/politics/ 2017/may/31/liar-liar-anti-theresa-may-song-heads-to-top-of-charts. 
Worrall, Simon. 2015. "True or False: Scandinavians are Practically Perfect in Every Way." National Geographic, 25 Feb. Accessed 3 July 2017. http://news.nationalgeographic.com/ news/2015/02/150225-scandinavia-finland-norway-sweden-denmark-culture-ngbooktalk/. 
